\title{
Fic1 Is Expressed at Apical Membranes of Different Epithelial Cells in the Digestive Tract and Is Induced in the Small Intestine During Postnatal Development of Mice
}

\author{
SASKIA W.C. VAN MIL, MASJA M. VAN OORT, INGE E.T. VAN DEN BERG, RUUD BERGER, \\ RODERICK H.J. HOUWEN, AND LEO W.J. KLOMP \\ Department of Pediatric Gastroenterology [S.W.C.v.M., R.H.J.H.], Department of Metabolic and \\ Endocrine Diseases [S.W.C.v.M., M.M.v.O., I.E.T.v.d.B., R.B., L.W.J.K.], University Medical Center,
}

Utrecht, The Netherlands

\begin{abstract}
Mutations in $A T P 8 B 1$ are associated with FIC1 disease, an autosomal recessive disorder in which intrahepatic cholestasis is the predominant manifestation. ATP8B1 encodes FIC1, which is expressed in several tissues, most prominently in the intestine, pancreas, and stomach and, to a much lesser extent, in the liver. In this study, Fic1 localization and expression during postnatal development was examined in healthy mice. Immunoblot and RT-PCR analysis indicated Fic1 is expressed abundantly in regions of the adult gastrointestinal tract of humans and mice. Immunohistochemistry revealed that Fic1 was localized to the apical membranes of enterocytes, pancreatic acinar cells, gastric pit epithelial cells, and hepatocytes and cholangiocytes. Subsequent analysis of early postnatal expression revealed that Fic1 expression in the small intestine was limited or absent at the age of 7 and $14 \mathrm{~d}$ and increased significantly with maturation. In contrast, pancreatic, hepatic, and gastric Fic1 expression was not diminished during the first $3 \mathrm{wk}$ of postnatal development. In
\end{abstract}

\section{ABSTRACT}

conclusion, these data show that Fic1 is expressed in a tissuespecific and developmentally regulated fashion at the apical membranes of epithelial cells. We speculate that the developing bile salt pool in the maturing intestine accounts for the increase in Fic1 protein expression in this tissue. (Pediatr Res 56: 981987, 2004)
Abbreviations
ASBT, apical sodium-dependent bile salt transporter
BRIC, benign recurrent intrahepatic cholestasis
FIC1, familial intrahepatic cholestasis 1
GFC, Greenland familial cholestasis
GGT, $\gamma$-glutamyltranspeptidase
IBABP, ileal bile acid binding protein
PFIC1, progressive familial intrahepatic cholestasis type 1
SCHAD, short chain L-3-hydroxyacyl-CoA

Bile acids, which are synthesized from cholesterol in the liver and secreted into the small intestine, play an important role in efficient digestion and absorption of dietary fats and fat-soluble vitamins $(1,2)$. Most bile acids are reabsorbed in the distal part of the ileum and cycle back to the liver via the portal venous system. Cholestasis, or impairment of bile flow, leads to malabsorption of fats and vitamins; hepatic accumulation of the toxic bile acids results in progressive liver damage. Hereditary cholestasis represents a heterogeneous group of severe pediatric disorders, which can be caused by deficiencies in

Received October 7, 2003; accepted May 12, 2004

Correspondence: Leo W.J. Klomp, M.D., Ph.D., University Medical Center Utrecht, Room KC02.069.1, Lundlaan 6, 3584 EA Utrecht, The Netherlands; e-mail: l.klomp@.azu.nl

Supported by Grant WS98-12 of the Dutch Digestive Disease Foundation (L.W.J.K., S.W.C.v.M.)

DOI: 10.1203/01.PDR.0000145564.06791.D1 primary bile acid synthesis or by deficiencies in the secretion of bile acids (3).

One of the familial intrahepatic cholestasis syndromes is FIC1 disease, which is caused by mutations in ATP $8 B 1$ $(4,5)$. Some FIC1 disease patients present with episodic bouts of cholestasis with no permanent liver damage; these patients suffer from BRIC (6-8). Alternatively, patients present with nonremitting cholestasis that progresses to severe permanent liver damage, referred to as PFIC1 (911), which also comprises GFC (12). In PFIC1, symptoms often occur during the first $6 \mathrm{mo}$, and children with PFIC1 die in the first decade of life unless liver transplantation or biliary diversion is performed. BRIC and PFIC1 are both associated with jaundice, pruritus, and diarrhea. Furthermore, FIC1 disease is invariably characterized by normal serum GGT activity and (episodic) high concentrations of bile salts in serum. 
Based on clinical and biochemical findings in FIC1 disease patients, it was proposed that FIC1, the polytopic membrane protein encoded by $A T P 8 B 1$, could function as a bile salt transporter $(4,5)$. FIC1 is, however, a member of the recently defined P4 P-type ATPase subfamily. This subfamily is well conserved during evolution and is present in all eukaryotes. It consists of at least 14 transporters in mice and humans that are thought to flip aminophospholipids from the outer to the inner plasma membrane leaflet $(13,14)$, but this function has been questioned (15). Ujhazy et al. (16) reported that in rat liver Fic1 displays aminophospholipid translocase activity, but how this molecular function relates to the phenotypes of FIC1 disease patients remains unknown. The biochemical and cellular function of FIC1 is therefore currently elusive.

In a previous report we examined FIC1 expression in the liver and showed that FIC1 is present in the canalicular membranes of hepatocytes and in cholangiocytes (17). FIC1 is even more abundantly expressed in the intestine $(4,16,17)$, consistent with recently obtained evidence from patients with PFIC1 and from a mouse model of PFIC1, which suggests that extrahepatic, notably intestinal, dysfunction is an important denominator of cholestasis in FIC1 disease (18-22). Thus, to further comprehend the putative role of the digestive tract in FIC1 disease, we set out to investigate the tissue distribution and cellular localization of Fic1 in stomach, pancreas, and intestine. Furthermore, because PFIC1 develops rapidly after birth, we studied Fic1 protein expression during immediate postnatal development of mice, when the bile acid pool develops to mature levels (23).

\section{METHODS}

Mice. All animals used in this study were healthy C57BL/6 mice that were maintained on a standard 12-h:12-h light:dark cycle and fed ad libitum. Mice were sacrificed at 7, 14, 21, 28, and $90 \mathrm{~d}$ after birth. For each time point, 10-15 mice were used and tissues were pooled. Weaning was approximately at $\mathrm{d} 21$. Tissues were snap frozen in liquid nitrogen and stored at $-80^{\circ} \mathrm{C}$ for RNA isolation, Western blot experiments, or immunohistochemistry on frozen sections. For immunohistochemistry on paraffin-embedded sections, tissues were fixed for $5 \mathrm{~h}$ in methanol: acetone: water (2:2:1), dehydrated through a graded series of ethanol, and embedded into paraffin using standard protocols. The animal committee of the University Medical Center Utrecht approved the animal experiments.

RT-PCR analysis of intestinal fragments. RNA was isolated from murine intestinal fragments using the RNeasy mini kit (QIAGEN, Valencia, CA). RNA from human intestine was obtained from Ambion (Austin, TX). cDNA was generated by RT-PCR using M-MLV (Promega, Madison, WI), and PCR analysis was performed using specific primers for human/ mouse ATP8B1 and human/mouse $18 S$ ribosomal RNA.

Western blot analysis. SDS-PAGE and Western blot analysis were performed essentially as described (17). Briefly, tissue homogenates were solubilized in sample buffer containing $20 \mathrm{mM}$ DTT and $10 \mathrm{mM}$ EDTA at room temperature for 15 min. After separation by SDS-PAGE, proteins were electrotransferred to nitrocellulose membranes $(0.45 \mu \mathrm{m}$; Protran,
Scheicher \& Schuell, Dassel, Germany) in a Bio-Rad transblot cell and blocked as described (24). The immunoblots were probed with anti-FIC1-C32 antiserum (see ref. 17) at 1:500 in blocking buffer. All results were reproduced with anti-FIC1-C6 (data not shown). As a control for protein loading, antibodies against SCHAD were used (1:5000), which were prepared in our laboratory (25). SCHAD is a house-keeping enzyme with an essential role in the mitochondrial beta-oxidation of short chain fatty acids (26). Immunoreactivity was detected with horseradish peroxidase-conjugated antibodies (1:10.000) and chemiluminescence (ECL, Amersham Pharmacia Biotech, Little Chalfont, Buckinghamshire, UK), according to the manufacturer's instructions.

Immunohistochemistry. Paraffin-embedded sections ( $8 \mu \mathrm{m})$ were dewaxed, rehydrated, and rinsed in PBS containing $0.1 \%$ Triton-X100. After boiling for $10 \mathrm{~min}$ in $0.01 \mathrm{M}$ sodium citrate buffer ( $\mathrm{pH} 6.0$ ), sections were blocked in $0.5 \%$ blocking reagent [supplied in tyramide signal amplification (TSA) fluorescein system: PerkinElmer Life Science, Boston, MA] in PBS containing $0.1 \%$ Triton-X100 and incubated with a 1:10 dilution of anti-FIC1-C6, preimmune serum, anti-FIC1-C6 preincubated with its antigen $(10 \mu \mathrm{L}$ of antiserum was incubated with $20-40 \mu \mathrm{g}$ of purified antigen for $1 \mathrm{~h}$ at $4^{\circ} \mathrm{C}$ ) or with anti-lactase (1:100, kindly provided by Dr. J. Dekker, Pediatric Gastroenterology and Nutrition, Erasmus University, Rotterdam, The Netherlands) for $16 \mathrm{~h}$ at $4^{\circ} \mathrm{C}$. After washing, endogenous peroxidase activity was blocked with $0.03 \% \mathrm{H}_{2} \mathrm{O}_{2}$. As secondary antibodies horseradish peroxidase (HRP)-conjugated goat anti-rabbit IgG (1:100; DAKO, Glostrup, Denmark) was used. HRP-based signal amplification was applied using the TSA fluorescein system procedure according to the manufacturer's descriptions. For indirect immunofluorescence, the protocol was stopped here and sections were examined by confocal microscopy. For light microscopy studies, the signal amplification procedure was followed by incubation with HRPconjugated rabbit anti-FITC IgG (1:100 DAKO) and staining for HRP-activity using 3,3'-diaminobenzidine (DAB) with nickel enhancement using standard protocols. Sections were counterstained with nuclear fast red (Sigma Chemical Co., St. Louis, MO), dehydrated and embedded into Euparal (CHROMA-Gesellschaft, Münster, Germany). For indirect immunofluorescence double-labeling experiments, cryostat sections $(6 \mu \mathrm{m})$ were incubated with anti-FIC1 antiserum and anti-cytokeratin $7 \mathrm{IgG}$ (DAKO) as described (17). Immunofluorescent labeling was visualized by confocal laser scan microscopy using a Nikon Eclipse E600 microscope.

\section{RESULTS}

FIC1 expression levels in different murine and human tissues of the gastrointestinal tract. To study ATP $8 B 1 \mathrm{mRNA}$ levels in the human gastrointestinal system, RT-PCR analysis was performed on RNA samples of different intestinal regions. As shown in Figure 1a, ATP8B1 mRNA is expressed in the human and mouse gastrointestinal system from the proximal to the distal end. To study the expression level of Fic1 protein in the mouse, tissues of healthy adult C57BL/6 mice were homogenized, and equal amounts of protein were separated by 
A.

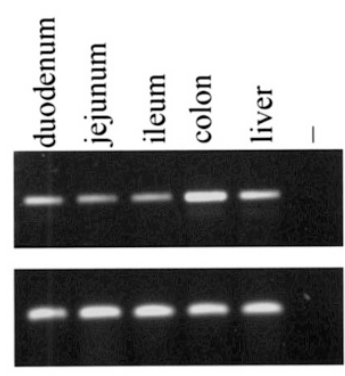

human

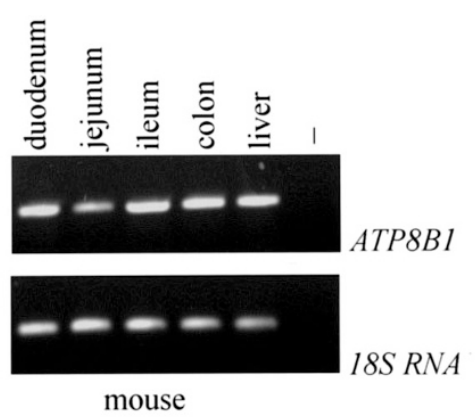

B.

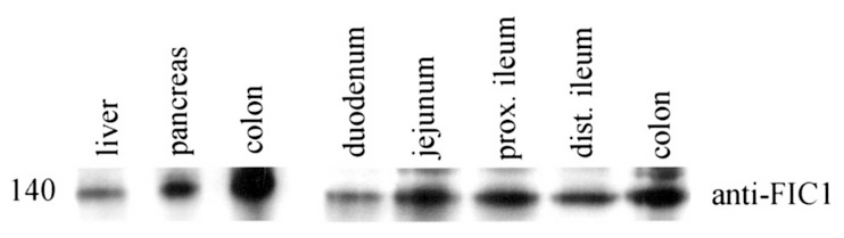

32

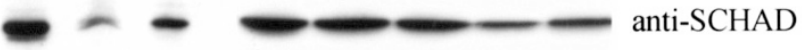

Figure 1. FIC1 expression in different human and mouse tissues. (A) cDNA was generated from RNA from different human and mouse intestinal fragments. PCR was performed using specific primers for human and mouse ribosomal RNA $(18 S)$ and $A T P 8 B 1 .(B, C)$ A total protein extract $(15 \mu \mathrm{g})$ of normal mouse liver, pancreas, and colon $(B)$ or different parts of the mouse intestine $(C)$ was separated by $6 \%$ and 12\% SDS-PAGE. After Western blotting, the membranes were incubated with anti-FIC1 or anti-SCHAD antisera (control for loading differences), respectively, followed by goat anti-rabbit peroxidase conjugated antibodies and immunoreactive proteins were visualized by chemiluminescence. Molecular size markers are indicated in kilodaltons $(\mathrm{kDa})$.

SDS-PAGE followed by immunoblotting with anti-FIC1 and anti-SCHAD antisera. The latter was used as a loading control. Previously, we have shown that our anti-human FIC1 antisera specifically detect FIC1 as a $140-\mathrm{kD}$ protein and cross-react with murine Fic1 (17). As shown in Figure 1b, Fic1 was readily detected in liver, but the expression was much higher in pancreas and colon (Fig. 1b). Fic1 protein expression in duodenum, jejunum, the proximal and distal part of the ileum, and colon was approximately equal (Fig. 1c), indicating that Fic1 protein expression in the mouse resembles ATP8B1 mRNA expression in humans.

Cellular and subcellular localization of Fic1 in the intestine, pancreas, and stomach. Immunohistochemistry experiments were performed to elucidate the cellular and subcellular localization of Fic1 in different murine tissues. As can be seen in Figure 2, a-e (left panels), Fic1 immunoreactivity was detected as a blue-purple precipitate at the apical membranes of the epithelial cells lining the intestinal lumen from the proximal to the distal end of the intestine. Intestinal goblet cells did not stain with the anti-FIC1 antiserum. Crypt cells stained inconsistently, but this was also observed after preincubation with the relevant antigen, therefore, we interpreted this as aspecific staining (results not shown). Preincubation of the antiserum with the antigen to which the antiserum was raised resulted in complete absence of immunoreactivity in all enterocytes (Fig. 2, a-e, right panels). A more intense staining overlapping with Fic1 immunoreactivity was seen with antilactase, a marker antibody for apical enterocyte expression in the ileum (Fig. 2f). Incubation of an ileal section with mouse preimmune serum showed no staining (Fig. $2 g$ ).

In the pancreas, Fic1 expression was detected in the exocrine tissue at the apical membranes of the acinar cells (Fig. 3a), whereas the endocrine islets of Langerhans were devoid of Fic1 staining. Fic1 was detected also at the apical membranes of epithelial cells lining the gastric pits (Fig. 3b). A complete absence of immunoreactivity was observed with preimmune serum (Fig. 3, $a$ and $b$ ) and when the anti-FIC1 antiserum was preincubated with the relevant antigen (results not shown). In immunohistochemistry experiments performed with lung, kidney, and heart sections Fic1 expression was below our detection limit (results not shown).

Ontogenesis of FIC1 expression in intestine, liver, pancreas, and stomach. In healthy rodents, the onset of active absorption of bile acids in the ileum occurs during the third postnatal week $(27,28)$. To investigate whether Fic1 levels change during postnatal development, tissues were collected from mice that were $7,14,21,28$, and $90 \mathrm{~d}$ old and analyzed by immunoblots with the anti-FIC1 and anti-SCHAD antisera. Below we show typical experiments obtained from independent homogenates. In duodenum and colon, limited but detectable Fic1 expression was noted at $\mathrm{d} 7$ and 14, which increased at $\mathrm{d} 21$. In the small intestine, hardly any Fic1 expression was detected at d 7 and 14, but Fic1 levels increased markedly during postnatal maturation (Fig. 4). Sections from jejunum and ileum of the different ages incubated with anti-FIC1 antiserum, also revealed absence of Fic1 immunoreactivity at $\mathrm{d} 7$ and 14, whereas Fic1 was localized at the brush border in intestines of 21-, 28-, and 90-d-old mice (results not shown). In contrast, in liver, pancreas, and stomach, Fic1 is already abundantly expressed at d 7 and 14 and is comparable during the postnatal development of the mice both on Western blot and immunohistochemistry (Fig. 5 and data not shown).

Ontogenesis of Fic1 expression in cholangiocytes. Previously, we reported that Fic1 was expressed at the apical membranes of hepatocytes and cholangiocytes (17). The Western blot experiments shown in Figure 5 do not discriminate between Fic1 expression in these cells. To investigate the ontogenesis of Fic1 expression in the liver, fluorescent doublelabeling experiments were performed on frozen liver sections of 14-d-old and adult mice. Cholangiocytes were identified by the specific marker anti-cytokeratin7. As shown in Figure 6, Fic1 is detected at the apical membranes of hepatocytes as well as in cholangiocytes already after $14 \mathrm{~d}$ of postnatal development.

\section{DISCUSSION}

Previously, we have studied the subcellular localization of Ficl in the liver (17). The present report focuses on the localization of Fic1 in the intestine, pancreas, and stomach, and its expression in these organs during ontogenesis. We now find 

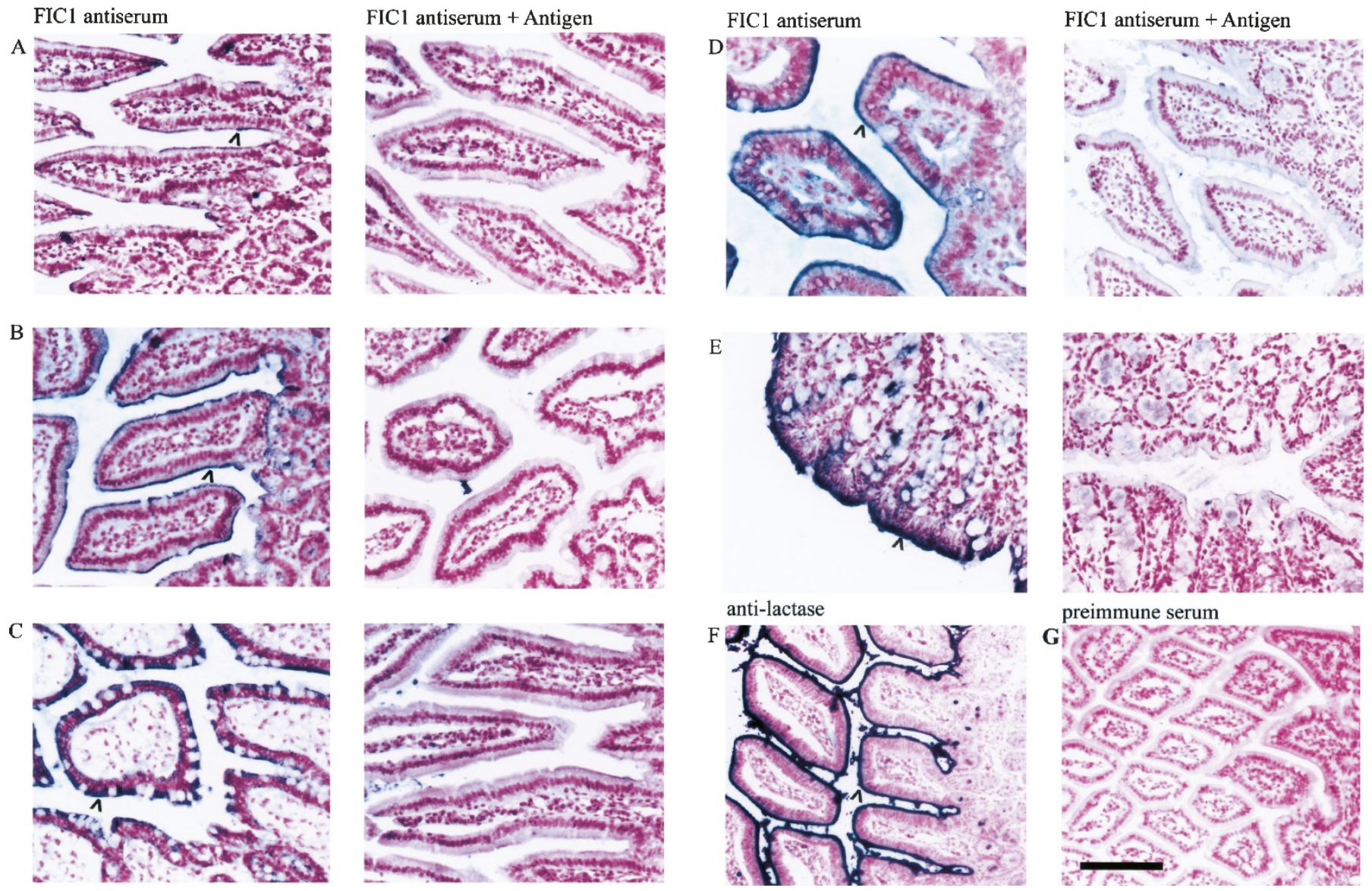

Figure 2. Subcellular localization of Fic1 in the intestine of mice. Paraffin-embedded sections of duodenum $(A)$, jejunum $(B)$, proximal $(C)$, and distal $(D)$ part of the ileum and colon $(E)$ of a healthy adult male mouse were incubated with the anti-FIC1 antiserum and the antiserum preincubated with the antigen. Ileal sections were also incubated with anti-lactase $(F)$ and rabbit preimmune serum $(G)$. After signal amplification, immunoreactivity was visualized with 1,2-di-amino benzidine (DAB). Open arrowheads point to apical membranes of enterocytes. Scale bar: $150 \mu \mathrm{m}$.

that Fic1 is expressed at the apical membranes of different epithelial cells in the entire digestive system. These data are consistent with the conclusion by Ujhazy et al. (16) that Fic1 is enriched in isolated brush border membrane vesicles of the rat intestine, but are in contrast to their finding that Fic1 expression is markedly lower in rat duodenum than in jejunum and ileum. Furthermore, our results indicate that Fic1 expression is specifically regulated in the intestine, but not in the liver, pancreas, and stomach, during early postnatal development of mice. Together with our previous work (17), these data provide a solid framework for our understanding of the function of FIC1 in relation to the development of hereditary cholestasis during childhood.

FIC1 expression in different epithelia, including in cells that are not involved in the enterohepatic circulation of bile acids, suggests that this protein is important in general cell biologic processes at the apical membrane. A pleiotropic function of FIC1 has also been proposed based on the homology of FIC1 to P4 P-type ATPases present in unicellular and multicellular eukaryotes. These P4 P-type ATPases are thought to function in aminophospholipid transport from the outer to the inner plasma membrane leaflet $(13,14,16)$ and in subcellular vesicle transport (29-31). A substantial overlap in the expression of the 14 proteins of the P4 P-type ATPase subfamily in man and mice was described (32). Partial redundancy in the function of these P4 P-type ATPases might explain why children suffering from FIC1 disease do not present with pathology in all tissues in which FIC1 is expressed. Further investigations are needed to elucidate the putative role of FIC1 in vesicle transport.

Nevertheless, it is obvious that the pleiotropic function of FIC1, inferred from our expression data and from the function of homologous proteins, is important in maintaining normal bile acid transport, because FIC1 disease patients suffer from cholestasis. Until recently, it was thought that FIC1 disease resulted from a primary deficiency in bile salt secretion from the liver $(4,5)$, but there is increasing evidence that other tissues play a role in this disease. The cholestasis completely resolved in two PFIC1 patients after biliary diversion (21) and in several patients treated by liver transplantation (18), but the children displayed severe diarrhea, failure to achieve catch-up growth, and appearance of steatosis in the new liver (20). Interestingly, many FIC1 disease patients also develop pancreatitis (33-37). Further evidence for the involvement of extrahepatic tissues in the etiology of FIC1 disease was obtained by analysis of mice with a homozygous missense mutation in Atp $8 \mathrm{bl}$; this mutation resulted in an amino acid residue replacement from glycine to valine $(\mathrm{G} 308 \mathrm{~V})$, a mutation also found in PFIC1 patients from Amish decent (4). In these mice 

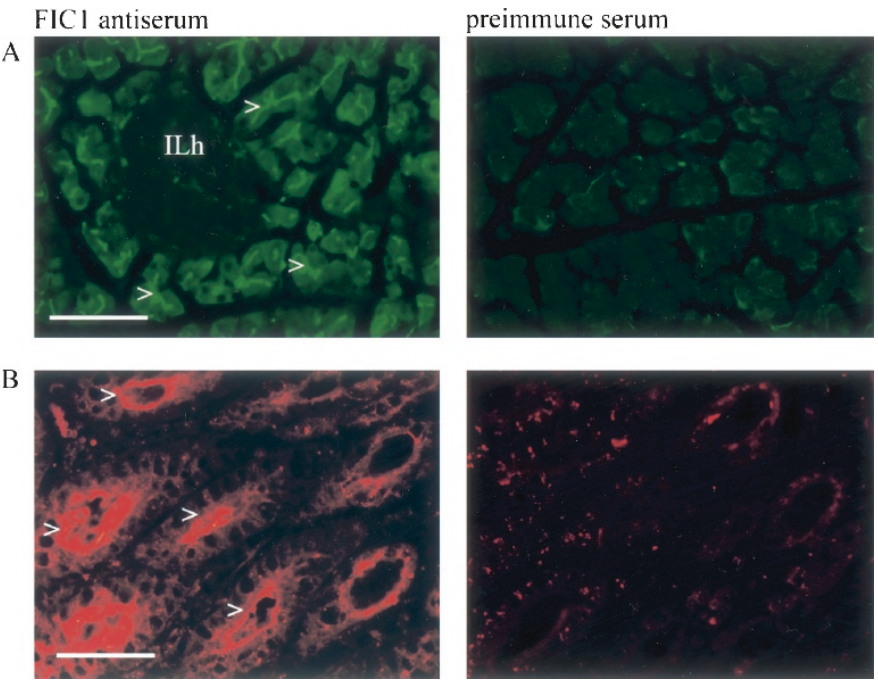

Figure 3. Subcellular localization of Fic 1 in murine pancreas and stomach Indirect immunofluorescence detection of Fic1 expression in murine pancreas $(A)$ and stomach $(B)$. Sections were incubated with anti-FIC1 antiserum or preimmune serum. ILh, islet of Langerhans. Open arrowheads point to pancreatic acinar membranes $(A)$ and apical membranes of cells lining the gastric pits $(B)$. Scale bars: $150 \mu \mathrm{m}$.

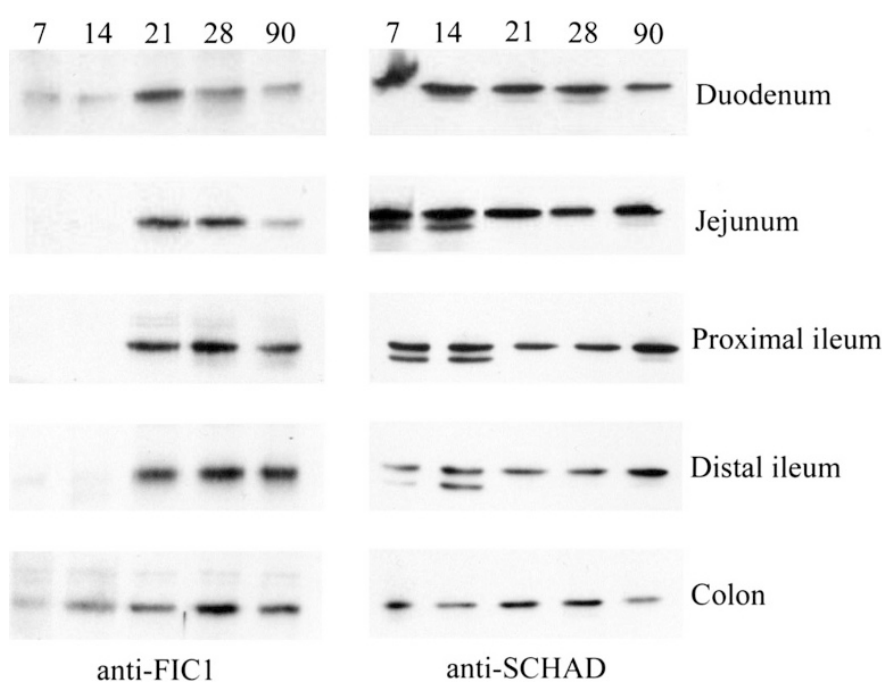

Figure 4. Fic1 expression in intestine during ontogenesis. In each lane, $15 \mu \mathrm{g}$ of protein extract from different intestinal fragments of 7-, 14-, 21-, 28-, and 90 -d-old mice was separated by $6 \%$ and $12 \%$ SDS-PAGE. After Western blotting, the membranes were incubated with anti-FIC1 antiserum, or antiSCHAD antiserum as a loading control, respectively. Proteins were visualized using a goat anti-rabbit peroxidase-conjugated antibody as in Figure 1.

no cholestasis was observed, but they developed a sustained accumulation of serum bile salts upon feeding a bile salt supplemented diet, whereas canalicular bile salt secretion was normal (22). The wild-type mice effectively maintained a low bile salt pool during bile salt overload, which indicated that the increased bile salt pool in $A t p 8 b 1^{\mathrm{G} 308 \mathrm{~V} / \mathrm{G} 308 \mathrm{~V}}$ mice was due to impaired regulation of resorption in the intestine or biliary epithelium. Taken together, the expression of Fic1 in different tissues described here can explain both the cholestasis as well as the extrahepatic pathology associated with FIC1 disease. This is in contrast to PFIC2 patients, who have a defect in the bile acid transporter BSEP, which is only expressed in the

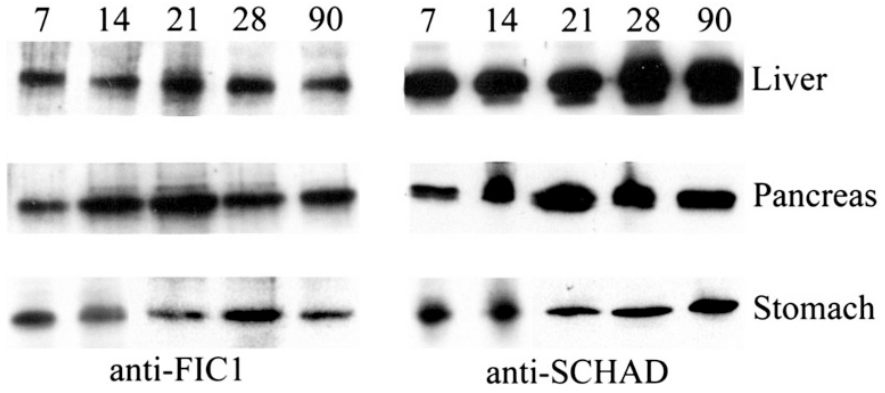

Figure 5. Fic1 expression in liver, pancreas, and stomach during ontogenesis. Total homogenates of murine liver, pancreas, and stomach were generated of 7-, 14-, 21-, 28-, and 90-d-old mice. Fic1 and SCHAD were visualized by immunoblotting with the anti-FIC1 and anti-SCHAD antibodies as in Figure 1.
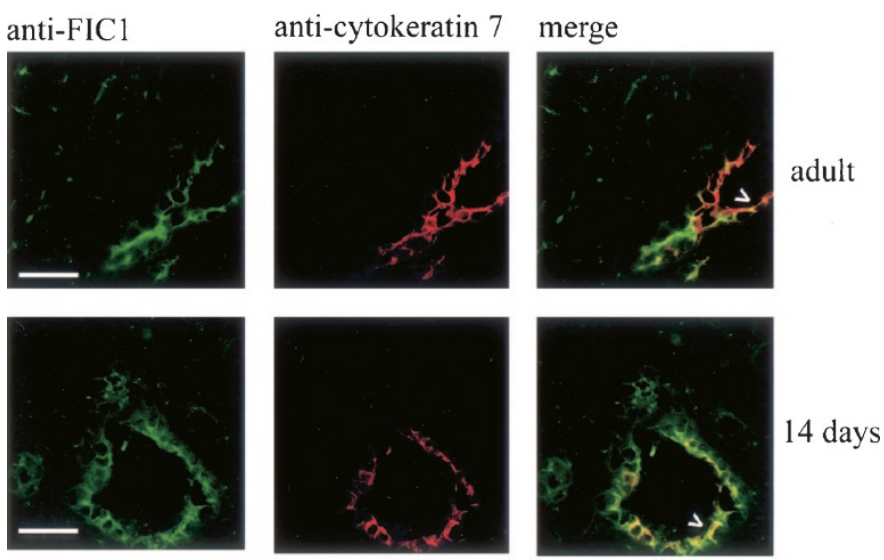

Figure 6. Fic1 expression during the ontogenesis of cholangiocytes. Frozen sections of livers of 14- and 90-d-old mice were analyzed by indirect confocal immunofluorescence using anti-FIC1 antiserum followed by TSA signal amplification (green fluorescence) and anti-cytokeratin 7 antibody as a marker for cholangiocytes (red fluorescence). Open arrowheads point to apical membranes of cholangiocytes. Scale bars: $30 \mu \mathrm{m}$.

canalicular membranes of hepatocytes. As far as currently known, infants suffering from PFIC2 display the same low GGT cholestasis but no extrahepatic complications, neither before nor after liver transplantation (20).

During the postnatal development of mammals, the enterohepatic circulation of bile acids develops $(27,28,38)$. This includes both bile acid synthesis in the liver as well as bile acid reabsorption in the intestine (39). In rodents, the maturation process of two cellular components of bile acid reabsorption in the intestine has been described in detail. Asbt, the apical bile salt importer at the enterocyte apical membrane (40), and the ileal bile acid binding protein, Ibabp, which appears to function as the cytosolic receptor for bile acids that have undergone sodium-dependent active transport by Asbt (28), are both expressed in the terminal part of the ileum, but only starting from the third week of postnatal life, when nursing stops. Both are transcriptionally regulated in part by nuclear hormone receptors, ASBT by the peroxisome proliferator-activated receptor $\alpha(\operatorname{PPAR} \alpha)(41)$ and Ibabp by the bile acid-dependent farnesoid X receptor (Fxr) (42). Fxr protein levels are also low in the rat ileum during the suckling period but increase during the third postnatal week (43). Here we show that Fic1 expression is specifically induced in the small intestine at $3 \mathrm{wk}$ of 
postnatal life. In contrast, Fic1 is expressed in other tissues before weaning and is not further induced during postnatal development. This tissue-specific developmental regulation of protein expression in the intestine is also described for Asbt. In the rat kidney, Asbt mRNA levels are also not changing upon weaning (44). Taken together with previous data, the up-regulation of intestinal Fic1 expression in healthy mice fed a cholate-supplemented diet $(22,45)$, and the induction of intestinal Fic1 expression by i.v. injection of taurocholate in rats (16), we propose that the developing bile salt pool in the maturing intestine accounts for the increase in Fic1 protein expression in this tissue. Interestingly, an increase in liver bile acid concentration imposed by bile duct ligation in rats did not result in changes in hepatic Fic1 expression (17) and FIC1 expression was also unchanged in patients with inflammation-induced icteric cholestasis (46). Furthermore, Fic1 protein expression in cholangiocytes is not induced concomitant with the maturation of the entero-hepatic circulation (Fig. 6). It would therefore be very interesting to investigate whether Fic1 gene expression is regulated specifically in the gut but not in the liver by bile acid sensors similar to the expression of ASBT and IBABP. However, Atp8b1 mRNA levels in the ileum of Fxr knockout mice are not distinguishable from wild-type mice, indicating that possible transcriptional regulation of Fic1 expression is not mediated by FXR (47). FIC1 itself has recently been implicated in regulating FXR expression, because ileal biopsies of PFIC1 patients showed decreased Fxr mRNA levels (48).

To infer the implications of this work for patients with FIC1 disease, it is imperative to carefully translate these findings to the human situation. The extrahepatic expression of ATP8BI mRNA is comparable to Fic1 protein expression in mice (Fig. 1 and ref (4)). Furthermore, similarly as in rodents, bile salt metabolism in humans quickly develops in the first months after birth $(23,49)$ and most PFIC1 patients have their first episode of cholestasis in this same period $(10,50)$. Assuming that in humans FIC1 expression parallels the maturation of bile acid metabolism as we describe here in mice, FIC1 is expressed in the human intestine just at or before the onset of FIC1 disease. We speculate that during immediate postnatal development passive absorption is replaced by active absorption of bile acids in the intestine and that FIC1 has an important role in this process, but the exact mechanisms await further studies. In human FIC1 disease, bile acid secretion is reduced, whereas it is normal in Atp8b1 $1^{G 308 V / G 308 V}$ mice (22), which might explain the occurrence of cholestasis in humans but not in Atp $8 b 1^{G 308 V / G 308 V}$ mice. This may reflect differences in how bile flow is regulated between these two species.

Acknowledgments. The authors thank Dr. J. Dekker (Erasmus University Rotterdam, the Netherlands) for gifts of the antilactase antibodies, Prof. Dr. R.P.J. Oude Elferink (Academic Medical Center, Amsterdam) for valuable discussions, and Dr. A.E.M. Klomp for critical evaluation of this manuscript.

\section{REFERENCES}

1. Muller M, Jansen PL 1998 The secretory function of the liver: new aspects of hepatobiliary transport. J Hepatol 28:344-354

2. Trauner M, Meier PJ, Boyer JL 1998 Molecular pathogenesis of cholestasis. N Engl J Med 339:1217-1227

3. Elferink RO, Groen AK 2002 Genetic defects in hepatobiliary transport. Biochim Biophys Acta 1586:129-145

4. Bull LN, van Eijk MJ, Pawlikowska L, DeYoung JA, Juijn JA, Liao M, Klomp LW, Lomri N, Berger R, Scharschmidt BF, Knisely AS, Houwen RH, Freimer NB 1998 A gene encoding a P-type ATPase mutated in two forms of hereditary cholestasis. Nat Genet 18:219-224

5. van Mil SW, Klomp LW, Bull LN, Houwen RH 2001 FIC1 disease: a spectrum of intrahepatic cholestatic disorders. Semin Liver Dis 21:535-544

6. Bijleveld CM, Vonk RJ, Kuipers F, Havinga R, Boverhof R, Koopman BJ, Wolthers BG, Fernandes J 1989 Benign recurrent intrahepatic cholestasis: altered bile acid metabolism. Gastroenterology 97:427-432

7. De Koning TJ, Sandkuijl LA, De Schryver JE, Hennekam EA, Beemer FA, Houwen RH 1995 Autosomal-recessive inheritance of benign recurrent intrahepatic cholestasis. Am J Med Genet 57:479-482

8. Summerskill WH, Walshe JM 1959 Benign recurrent intrahepatic obstructive jaundice. Lancet 2:686-690

9. Bull LN, Carlton VE, Stricker NL, Baharloo S, DeYoung JA, Freimer NB, Magid MS, Kahn E, Markowitz J, DiCarlo FJ, McLoughlin L, Boyle JT, Dahms BB, Faught PR, Fitzgerald JF, Piccoli DA, Witzleben CL, O'Connell NC, Setchell KD, Agostini RM Jr, Kocoshis SA, Reyes J, Knisely AS 1997 Genetic and morphological findings in progressive familial intrahepatic cholestasis (Byler disease [PFIC-1] and Byler syndrome): evidence for heterogeneity. Hepatology 26:155-164

10. Clayton RJ, Iber FL, Ruebner BH, McKusick VA 1969 Byler disease. Fatal familial intrahepatic cholestasis in an Amish kindred. Am J Dis Child 117:112-124

11. Linarelli LG, Williams CN, Phillips MJ 1972 Byler's disease: fatal intrahepatic cholestasis. J Pediatr 81:484-492

12. Klomp LW, Bull LN, Knisely AS, van Der Doelen MA, Juijn JA, Berger R, Forget S, Nielsen IM, Eiberg H, Houwen RH 2000 A missense mutation in FIC1 is associated with Greenland familial cholestasis. Hepatology 32:1337-1341

13. Mouro I, Halleck MS, Schlegel RA, Mattei MG, Williamson P, Zachowski A, Devaux P, Cartron JP, Colin Y 1999 Cloning, expression, and chromosomal mapping of a human ATPase II gene, member of the third subfamily of P-type ATPases and orthologous to the presumed bovine and murine aminophospholipid translocase. Biochem Biophys Res Commun 257:333-339

14. Tang X, Halleck MS, Schlegel RA, Williamson P 1996 A subfamily of P-type ATPases with aminophospholipid transporting activity. Science 272:1495-1497

15. Siegmund A, Grant A, Angeletti C, Malone L, Nichols JW, Rudolph HK 1998 Loss of Drs $2 p$ does not abolish transfer of fluorescence-labeled phospholipids across the plasma membrane of Saccharomyces cerevisiae. J Biol Chem 273:34399-34405

16. Ujhazy P, Ortiz D, Misra S, Li S, Moseley J, Jones H, Arias IM 2001 Familial intrahepatic cholestasis 1: studies of localization and function. Hepatology 34:768-775

17. Eppens EF, van Mil SW, de Vree JM, Mok KS, Juijn JA, Oude Elferink RP, Berger R, Houwen RH, Klomp LW 2001 FIC1, the protein affected in two forms of hereditary cholestasis, is localized in the cholangiocyte and the canalicular membrane of the hepatocyte. J Hepatol 35:436-443

18. Bhagat G, Lobritto SJ, Lefkowitch JH, Bourke B, Mc Dermott M, Portmann BC 2001 Allograft steatosis is a feature of progressive familial intrahepatic cholestasis type 1 (FIC1 disease), treated by orthopic liver transplantation (OLTX). Hepatology 34:209A

19. Coleman R, Iqbal S, Godfrey PP, Billington D 1979 Membranes and bile formation. Composition of several mammalian biles and their membrane-damaging properties. Biochem J 178:201-208

20. Lykavieris P, van Mil S, Cresteil D, Fabre M, Hadchouel M, Klomp L, Bernard O, Jacquemin E 2003 Progressive familial intrahepatic cholestasis type 1 and extrahepatic features: no catch-up of stature growth, exacerbation of diarrhea, and appearance of liver steatosis after liver transplantation. J Hepatol 39:447-452

21. van Ooteghem NA, Klomp LW, van Berge-Henegouwen GP, Houwen RH 2002 Benign recurrent intrahepatic cholestasis progressing to progressive familial intrahepatic cholestasis: low GGT cholestasis is a clinical continuum. J Hepatol 36:439-443

22. Pawlikowska L, Groen A, Eppens EF, Kunne C, Ottenhoff R, Looije N, Knisely AS, Killeen NP, Bull LN, Elferink RP, Freimer NB 2004 A mouse genetic model for familial cholestasis caused by ATP8B1 mutations reveals perturbed bile salt homeostasis but no impairment in bile secretion. Hum Mol Genet 13:881-892

23. Suchy FJ, Bucuvalas JC, Novak DA 1987 Determinants of bile formation during development: ontogeny of hepatic bile acid metabolism and transport. Semin Liver Dis 7:77-84

24. Klomp AE, Tops BB, Van Denberg IE, Berger R, Klomp LW 2002 Biochemical characterization and subcellular localization of human copper transporter 1 (hCTR1). Biochem J 364:497-505

25. Klomp AE, van de Sluis B, Klomp LW, Wijmenga C 2003 The ubiquitously expressed MURR1 protein is absent in canine copper toxicosis. J Hepatol 39:703-709

26. Vredendaal PJ, van den Berg IE, Malingre HE, Stroobants AK, Olde Weghuis DE, Berger R 1996 Human short-chain L-3-hydroxyacyl-CoA dehydrogenase: cloning and characterization of the coding sequence. Biochem Biophys Res Commun 223:718-723

27. Heubi JE, Fondacaro JD 1982 Postnatal development of intestinal bile salt transport in the guinea pig. Am J Physiol 243:G189-G194

28. Hwang ST, Henning SJ 2000 Hormonal regulation of expression of ileal bile acid binding protein in suckling rats. Am J Physiol Regul Integr Comp Physiol 278:R1555-R1563 
29. Chen CY, Ingram MF, Rosal PH, Graham TR 1999 Role for Drs2p, a P-type ATPase and potential aminophospholipid translocase, in yeast late Golgi function. J Cell Biol 147:1223-1236

30. Hua Z, Fatheddin P, Graham TR 2002 An essential subfamily of Drs2p-related P-type ATPases is required for protein trafficking between Golgi complex and endosomal/ vacuolar system. Mol Biol Cell 13:3162-3177

31. Pomorski T, Lombardi R, Riezman H, Devaux PF, van Meer G, Holthuis JC 2003 Drs2p-related P-type ATPases Dnf1p and Dnf2p are required for phospholipid translocation across the yeast plasma membrane and serve a role in endocytosis. Mol Biol Cell 14:1240-1254

32. Halleck MS, Lawler JF Jr, Blackshaw S, Gao L, Nagarajan P, Hacker C, Pyle S, Newman JT, Nakanishi Y, Ando H, Weinstock D, Williamson P, Schlegel RA 1999 Differential expression of putative transbilayer amphipath transporters. Physiol Genomics 1:139-150

33. Egawa H, Yorifuji T, Sumazaki R, Kimura A, Hasegawa M, Tanaka K 2002 Intractable diarrhea after liver transplantation for Byler's disease: successful treatment with bile adsorptive resin. Liver Transpl 8:714-716

34. Knisely AS, Boyle JT, Naylor EW, Klinger K, Freimer N, Kocoshis SA 1995 Pancreatic disfunction in Byler disease. J Pediatr Gastroenterol Nutr 21:328(abstr)

35. Knisely AS 2000 Progressive familial intrahepatic cholestasis: a personal perspective. Pediatr Dev Pathol 3:113-125

36. Tygstrup N 1960 Intermittent possibly intrahepatic cholestatic jaundice. Lancet 1:1171-1172

37. Tygstrup N, Steig BA, Juijn JA, Bull LN, Houwen RH 1999 Recurrent familial intrahepatic cholestasis in the Faeroe Islands. Phenotypic heterogeneity but genetic homogeneity. Hepatology 29:506-508

38. Little JM, Lester R 1980 Ontogenesis of intestinal bile salt absorption in the neonata rat. Am J Physiol 239:G319-G323

39. Stahl GE, Mascarenhas MR, Fayer JC, Shiau YF, Watkins JB 1993 Passive jejuna bile salt absorption alters the enterohepatic circulation in immature rats. Gastroenterology 104:163-173

40. Shneider BL, Dawson PA, Christie DM, Hardikar W, Wong MH, Suchy FJ 1995 Cloning and molecular characterization of the ontogeny of a rat ileal sodiumdependent bile acid transporter. J Clin Invest 95:745-754
41. Jung D, Fried M, Kullak-Ublick GA 2002 Human apical sodium-dependent bile salt transporter gene (SLC10A2) is regulated by the peroxisome proliferator-activated receptor alpha. J Biol Chem 277:30559-30566

42. Hwang ST, Urizar NL, Moore DD, Henning SJ 2002 Bile acids regulate the ontogenic expression of ileal bile acid binding protein in the rat via the farnesoid $\mathrm{X}$ receptor. Gastroenterology 122:1483-1492

43. Hwang ST, Urizar NL, Moore DD, Henning SJ 2002 Bile acids regulate the ontogenic expression of ileal bile acid binding protein in the rat via the farnesoid $\mathrm{X}$ receptor. Gastroenterology 122:1483-1492

44. Christie DM, Dawson PA, Thevananther S, Shneider BL 1996 Comparative analysis of the ontogeny of a sodium-dependent bile acid transporter in rat kidney and ileum. Am J Physiol 271:G377-G385

45. Pawlikowska L, Ottenhoff R, Looije N, Eppens EF, Knisely AS, Bull LN, Oude Elferink RP 2001 FIC1 mutant mice have a defect in the regulation of intestinal bile acid absorption. Hepatology 34:240A

46. Zollner G, Fickert P, Zenz R, Fuchsbichler A, Stumptner C, Kenner L, Ferenci P, Stauber RE, Krejs GJ, Denk H, Zatloukal K, Trauner M 2001 Hepatobiliary transporter expression in percutaneous liver biopsies of patients with cholestatic liver diseases. Hepatology 33:633-646

47. Kok T, Hulzebos CV, Wolters H, Havinga R, Agellon LB, Stellaard F, Shan B, Schwarz M, Kuipers F 2003 Enterohepatic circulation of bile salts in farnesoid X receptor-deficient mice: efficient intestinal bile salt absorption in the absence of ileal bile acid-binding protein. J Biol Chem 278:41930-41937

48. Chen F, Ananthanarayanan M, Emre S, Neimark E, Bull LN, Knisely AS, Strautnieks SS, Thompson RJ, Magid MS, Gordon R, Balasubramanian N, Suchy FJ, Shneider BL 2004 Progressive familial intrahepatic cholestasis, type 1, is associated with decreased farnesoid X receptor activity. Gastroenterology 126:756-764

49. de Belle RC, Vaupshas V, Vitullo BB, Haber LR, Shaffer E, Mackie GG, Owen H, Little JM, Lester R 1979 Intestinal absorption of bile salts: immature development in the neonate. J Pediatr 94:472-476

50. Whitington PF, Freese DK, Alonso EM, Schwarzenberg SJ, Sharp HL 1994 Clinical and biochemical findings in progressive familial intrahepatic cholestasis. J Pediatr Gastroenterol Nutr 18:134-141 